\title{
The Transition to a Market Economy:
}

\section{The Experience of Algeria}

\author{
Mokhtar Kheladi, Baya Arhab \\ University of Béjaïa, Béjaïa, Algeria
}

\begin{abstract}
In the mid-sixties, Algeria opted for a state-led development strategy based on heavy industry, planning and public sector. The vowed target was to catch up the developed countries within two decades. However, the country sounds having overestimated its capacities (technology, skilled labor force...). The failure of this strategy is announced in the 1988 social unrest and riots that resulted from the worsening socio-economic situation since the 1986 oil choc. In effect, the legacy of two decades of planning and billion dollars' investment expenditure was disastrous: soaring unemployment, increasing poverty, deficient huge public sector, complete dependency on import of food, medicines, consumer durables... and terrorism. In the face of such a situation and squashed by the rising foreign debt service while hard currency revenues were lowering, public authorities were bound to reform the system. This is how Algeria embarked on stabilization and structural adjustment programs with the aim of setting up the mechanisms of a market economy. The period of transition from planned to a market economy that ought to be as short as possible is running for almost two decades now. As a result, the whole country is thrown in a sort of no-man's-land where neither the rules of socialism nor those of capitalism play. This paper examines the difficulties posed by the introduction of market mechanisms in Algeria and the damaging consequences of not completing the reforms. It also explores the main actions required to dig up the country from the black hole of a too long transition and let its huge growth prospects materialize.
\end{abstract}

Keywords: growth, market economy, private investment, competitiveness, unemployment, transition

\section{Introduction}

Algeria became independent about a half-century ago after 132 years of a hard colonization which hurts its institutions, economy and culture. Therefore, the first concern of the Algerian authorities was to build a powerful state that would not disappear with men (dixit the President H. Boumediène). Wishing to cut all links with the capitalist system, viewed at that time as the source of colonialism, the new authorities chose the way of socialism and sought inspiration and aid from the USSR. A no mercy struggle against foreign enterprises (which are nationalized) and the private local sector (which is hunted until near-disappearing) was conducted to make room

Mokhtar Kheladi, Ph.D., Professor in Economics, Faculty of Economics and Management, University of Béjaïa.

Baya Arhab, Ph.D., Lecturer in Economics, Faculty of Economics and Management, University of Béjaïa.

Correspondence concerning this article should be addressed to Baya Arhab (Mokhtar Kheladi), Faculté des sciences économiques, université A. MIRA de Béjaïa, route de Tichy, Béjaïa 06000, Algérie. E-mail: b.arhab_univbj@yahoo.fr (mokhtarkheladi@yahoo.fr). 
to an over-sized state. The later imposed itself as the main owner of the means of production and took control of all important activities: investment, foreign trade, education and some others fields. Threading in the USSR footsteps, Algeria opted for heavy industry, planning and public sector. The vowed target was to realize the miracle of catching up the developed countries. After less than a quarter of century, the failure of the project is announced in the 1988 social unrest and riots. The dramatic socio-economic situation that followed these events prompted the government to set up the process of a transition to the market economy, which means returning to all the principles that have been severely criticized and banished since the mid-sixties. Today, having embarked on a structural program for two decades, it seems that Algeria has settled in between socialism and the market economy, a situation that is extremely damaging as it seriously impedes the exploitation of the country's growth potential.

The experience of Algeria in matter of transition deserves to be shared. The purpose of this paper is to find out and understand what factors delay the process of transiting from the previous system to the new one. Section 1 recalls the main features of the Algerian economy during the period of the state monopoly. Section 2 examines and evaluates the outcomes of the public actions and reforms intended to lay the basis of a market economy. Section 3 reviews the growth prospects of the country and the necessary actions to let them materialize.

\section{The Algerian Economy at Glance}

For a neutral observer, Algeria appears as the country of paradoxes; it is potentially rich but really poor; its feet are rooted in Africa, its head float near Europe and its mind is rooted in the Middle-East; it spent a quarter of century walking in one way and the following quarter of century going in the opposite way... Perhaps, that can be explained by the fact that the country is vast and diversified (geographically, culturally, historically...). It goes without saying that we can't recall all about Algeria's economy in few lines, so we limit ourselves to the main features which make us understanding its evolution during the last half-century.

\section{Some General and Macro-economic Data}

Located in North Africa and south Europe, Algeria is the second largest country in Africa and the tenth in the world, with a territory of 2,381,741 $\mathrm{km}^{2}$ where lives, a population of more than 36 million of souls. But this large territory is eaten by the desert of Sahara, letting nothing but a narrow ribbon of 1,000 $\times 100 \mathrm{~km}$ along the Mediterranean Sea (see Figure 1). To make things worse, more than $80 \%$ of this area where are gathered more than $75 \%$ of the population and activities, are occupied by mountains. So, we are allowed to say that Algeria is in fact a small country. Fortunately, the huge Sahara which seems useless and wasted is full of precious products and raw materials such as oil, gas, gold, uranium, phosphate, iron. This unbalanced territory makes the planning and management of the country difficult besides raising the problem of ensuring social justice ${ }^{1}$.

Algeria appears among the handful African countries with a GDP exceeding 150 billion dollars, but this is a misleading figure as it hides more than it shows. We should note that hydrocarbons supply between $30 \%$ and $50 \%$ of the country's GDP and $98 \%$ of its hard currency (see Figure 2). In the meantime, the contribution of agriculture amounts to about $10 \%$ of GDP and the share of the public industrial sector is limited to only $5 \%$ of

\footnotetext{
${ }^{1}$ As a matter of fact, it is extremely difficult to provide with basic need goods; populations dispersed over millions $\mathrm{km}^{2}$ of hostile desert; because citizen in the South of the country must find in the store the same goods as there is in the North, at the same price.
} 
GDP (retrieved from http://www.minagri.dz). The wealth and the prosperity of the country are strongly tied to the movement of the crude oil price on international markets and Algerians are reduced to pray every day, hoping that the price of this commodity will never fall. This architecture of the economy hampers the increase of non-hydrocarbons exports while the government aims at bringing their amount to two billion dollars for more than a decade. It's enough to lighten the watcher, warning him that despite its ranking at the scale of Africa, Algeria remains a genuine under-developed country. That is what the main macro-economic variables indicate.

GDP per capita (PPP) turns around 7,500 dollars, depending on the oil price evolution ${ }^{2}$ and the weather which determines the level of the agricultural production. Needless to say that it is an average value and eradicating poverty remains among the government objectives. Let us just recall that beside the million unemployed, about 250,000 people occupied through General Interest Activities, perceive less than 1/5 of the minimum wage; more than 620,000 persons have benefited from social transfers in 2007 while in the remote areas of the country many households are bound to rely on charity.
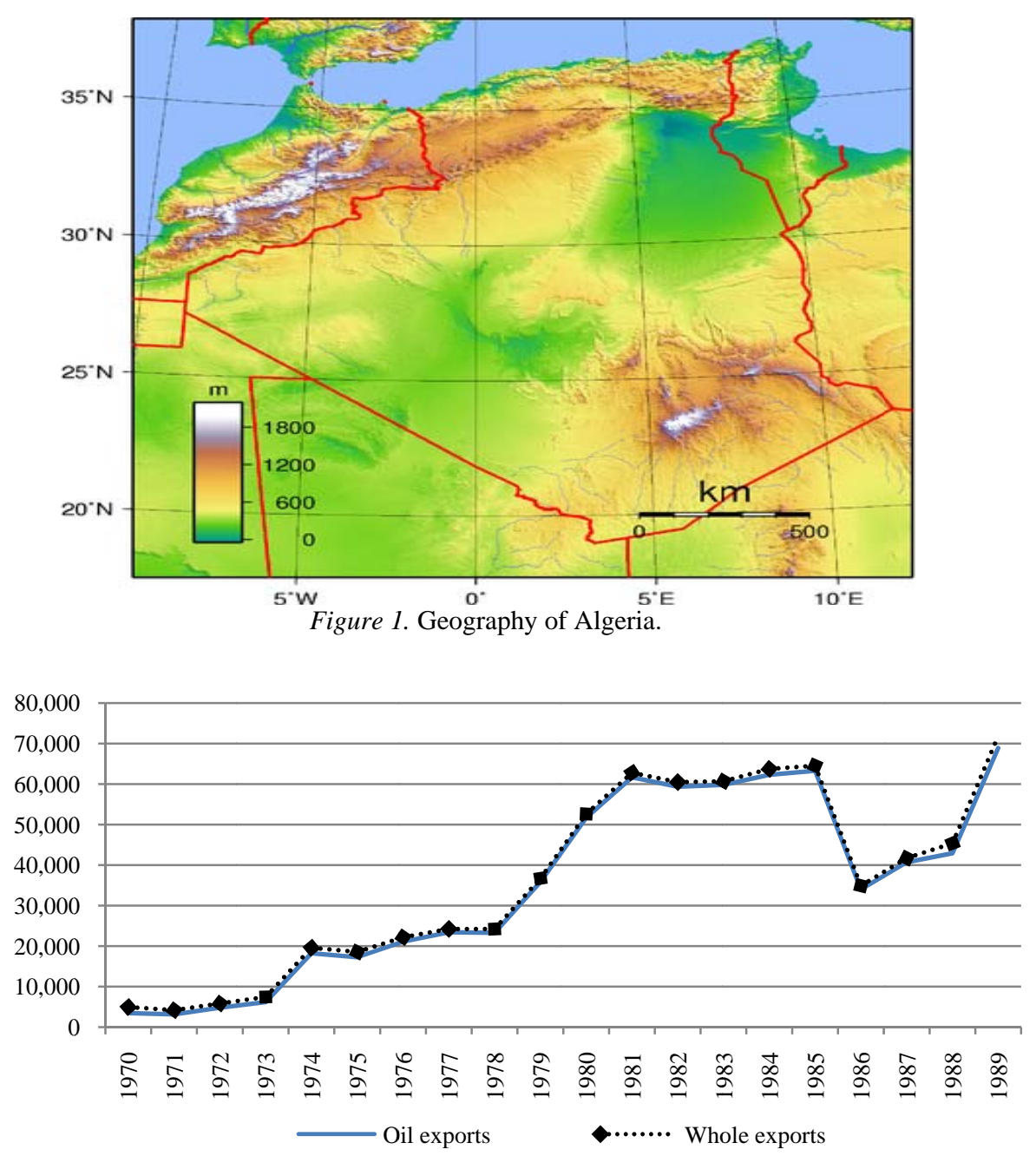

Figure 2. The weight of oil in Algerian exports. Source: ONS.

\footnotetext{
${ }^{2}$ For example Algeria's oil exports amount to 59.5 billion dollars in 2007, 77 billion dollars in 2008, and only 44.3 billion dollars in 2009 (Sonatrach, 2009).
} 
The unemployed population, in the acceptance of the ILO, amounts to $1,076,000$, which makes an unemployment rate of $10 \%$ in 2010.

Inflation measured by the evolution of the consumption prices index, started soaring since mid-2000. It increased from $1.8 \%$ in 2006 to $3.9 \%$ in 2008 to reach $6.4 \%$ in 2009. This is a consequence of the government spending and the increase of the agricultural and food products prices on the world market.

\section{The Agricultural Sector}

It pleases the Algerians to recall themselves that their country was the breadbasket of Roma. This is the part of the myth of Algerian agriculture which is unable nowadays to supply the population with the necessary food products. The sector suffers from several difficulties and weaknesses:

(1) The soil shortage: Desert and mountains take more than $95 \%$ of the territory and the remaining $5 \%$ are at the core of a great conflict between agriculture, urbanization, industrialization, tourism, and so on. Today, the country owns a useful agricultural area (UAA) of about 8.5 millions of hectares and it seems that this surface constitutes a sort of threshold and can't be extended, despite the efforts of the government to increase it. Beside the steadiness of the UAA, the population continues to increase even though at a low rate and it happens that part of the UAA is diverted for other uses; consequently, the UAA per se goes lowering. Actually, it reaches the value of 0.3 hectare, and it is expected to continue to decrease, threatening the country of starvation, if radical solutions aren't found urgently;

(2) The scarcity of the water: Rain is rare and irregular in the space and the time;

(3) The dividing up of the land: In the Algerian law and following the teachings of Islam, the estate is divided between all the heirs. Consequently, after two or three generations, the surface of landed estate becomes too limited to be economically exploited;

(4) The lack of investment: Believing that promoting industry is the best way to reach the level of the developed countries within few years, Algeria decides to throw its entire means and energies in this sector, neglecting agriculture (see Figure 3) which is viewed as a sign of under-development.

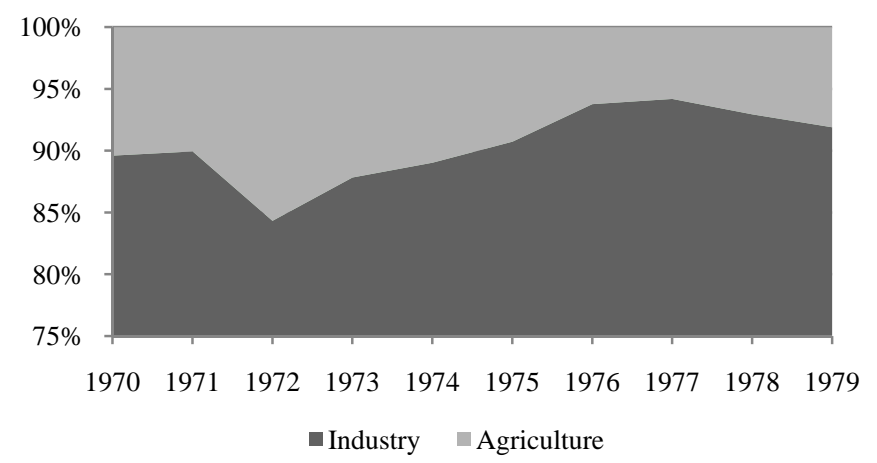

Figure 3. Investment in the sectors of industry and agriculture over the period of 1970/1979. Source: Ministère de la Planification et de l’Aménagement du Territoire.

The disastrous performance of its agriculture leads Algeria to import great quantities of crops, milk, sugar, vegetable oils, meat, fruits, potatoes, and so on (see Table 1). The country is today heavily and dangerously dependent on international markets for its food needs. 
Table 1

Evolution of Algeria's Imports (Million Dinars)

\begin{tabular}{lcccc}
\hline & 1967 & 1972 & 1977 & 1982 \\
\hline Milk and its derivatives & 94.7 & 188.5 & 110.1 & 889.1 \\
Butter & 12.2 & 62.3 & 80.3 & 526.1 \\
Eggs & - & - & 63.7 & 355.1 \\
Coffee & 124.3 & 260.8 & 360.5 & 477.5 \\
Wheat & 385.2 & 297.9 & 801.4 & $1,876.5$ \\
Barley & 11.8 & 17.6 & 72.4 & 387.5 \\
Vegetal oil & 48.4 & 95.3 & 387.7 & 602 \\
\hline
\end{tabular}

Note. Source: ONS.

\section{The Industrial Sector}

During French colonization, Algeria was expected to be the main provider of France with raw materials and agricultural products, and it receives in exchange industrial products. Consequently, at the time of independence, the bulk of the population lives in the agricultural sector as industry was limited to the strict necessary for the good functioning of the colonial economy. Considering this specialization as the major source of underdevelopment, the government decided to built a strong heavy industry, with the aim of freeing the people and leading them, within a quarter of century, to the state of development. However, the country owns neither the sharp technology nor the billions of dollars required to realize such an ambitious project. Acting as they did, the national authorities made double error of judgment:

- They believed that technology is going alongside with the sophisticated equipments. Buying this kind of equipments from the developed countries ensures us that we obtain and master the technology;

- They thought that it is possible to offset the lack of funds by resorting to the international capital market. When the whole production system enters the operating stage, it would be easy to repay the foreign debts, even if the rate of interest is high, as long as the rate of profit overtakes it.

Such naïve reasoning led directly to the failure of the Algerian development strategy. The shortcomings of this strategy appeared by the mid-eighties following the abrupt drop of oil price that fall from 28 to 14 dollars, in June 1986. Consequently, the country lost half of its foreign resources at a time where the bulk of its foreign debts were falling due. At the moment, everyone realized that the big public-owned enterprises expected to provide the domestic market with goods and to export are far from fulfilling their mission. Furthermore, not only the country was unable to export and gain hard currency; but it did not succeed to substitute for the goods that it uses to import before spending hundreds of billions dollars to sow blindly hundreds factories all over the territory. In most cases, the factories operate at less than $30 \%$ of their optimal capacities and the bad quality of their products made them being non-competitive even on the domestic market. The state tried to foster local production by closing its boundaries in the face of foreign products, rewarding in so doing weakness and under-competitiveness. Then the government decides to introduce several reforms that proved to be superficial and far from touching the roots of the problems (Benissad, 1991). As long as the price of the oil barrel remained high, the difficulties are overcame and covered up but when it fell, the catastrophic management of the national economy appeared as the sun of midday. 
Table 2

Index of Industrial Production of the Public Sector (Base 100,1989)

\begin{tabular}{|c|c|c|c|c|c|c|c|c|}
\hline & 1994 & 1995 & 1996 & 1997 & 1998 & 1999 & 2000 & 2001 \\
\hline General index & 88.4 & 87.6 & 81.5 & 78.5 & 84 & 84 & 85 & 85 \\
\hline Outside hydrocarbons & 84.2 & 82.9 & 74.1 & 69.3 & 76 & 75 & 75 & 75 \\
\hline Manufacturing industries & 80.1 & 79.9 & 68.7 & 63.4 & 69 & 68 & 67 & 66 \\
\hline ISMME & 68.2 & 74.5 & 59.6 & 47.9 & 53 & 55 & 57 & 63 \\
\hline Agro-food, tobacco, matches & 96.4 & 89.0 & 85.5 & 83.1 & 95 & 94 & 85 & 75 \\
\hline Textile, confection & 82.5 & 73.1 & 53.1 & 49.1 & 48 & 39 & 33 & 29 \\
\hline Leather and shoes & 53.5 & 42.6 & 29.3 & 23.7 & 22 & 17 & 16 & 15 \\
\hline
\end{tabular}

Note. Source: ONS: 1994-1997: CNES(1999) and Bedrani (2002).

In early nineties, the Algerian economy was at the edge of the bankruptcy. The state has renounced for some of its social and economic activities; firms suffered from a lack of imported raw materials and spare parts as they were starved of foreign currency, leading them to stop functioning; workers were not perceiving their wages; the products of basic needs were no more subsidized. This situation caused strikes that evolved to gigantic riots, threatening the basis of the Republic. The time of courageous and deep reforms was arrived as Algeria had to choose between exploiting its potential to become rich and prosperous or to remain underdeveloped and poor, opening doors to different kinds of violence, social unrest and all forms of extremisms. With the back to the wall, the government calls the IMF, for help.

\section{The Transition to a Market Economy}

Following the mid-1980 crisis, the government introduced some reforms (the liberalization of several activities starting from 1989, the law on money and credit in 1990, new investment code in 1993...) with an attempt to solve its financial problems by itself, without the help of any foreign intervention. But these reforms were not deep enough and did not address the root causes of the country's problems. In the meantime, the economy was suffocating under the pressure of the financial constraint as the country's resources were cut exactly at the moment when it desperately needed them. In fact, the value of exports (between 9 and 10 billion dollars) was just enough to either cover the imports that amount roughly 8 to 9 billion dollars or repay the falling due external debt (the debt service amounts to about 8 billion dollars). After several months of hesitation, and as the socio-economic situation was worsening, the government finally decided to beg the help of the IMF in order to obtain the right of negotiating the re-scheduling of its debt. The fund submits the country to the rules of the Washington Consensus: liberalization, privatization, devaluating, openness, stabilization of the macro-economic main variables, ousting of the state from the economic field... We will examine in this second section the transition process as it is conducted in Algeria and try to explain why the introduction of the main market mechanisms takes so long.

\section{The Transition and Its Outcomes}

The set of actions that Algeria applied under the control of the IMF, usually known under the Structural Adjustment Program (SAP) aims at sparing foreign currency and making available the necessary amount to repay the creditors. The SAP that was implemented during the period of 1994/1998 is considered as the first significant step in the process of the transition to a market economy. The main actions undertaken with this purpose are the followings. 


\section{Privatization}

Under the socialist era, Algeria built up an important industrial public sector composed of large state-owned enterprises and small units, the property of the local collectivities. Globally, the whole of this public estate is ill-managed and operates at very low level of its real capacities. This is especially true of the small firms which became financial abysses (Madouche, 1988), the reason why the process of privatization hurts violently the small and medium enterprises (SMEs). These are abruptly declared bankrupt and closed, freeing about a half-million workers whom goes adding to 2 million yet existing jobless. The privatization of greater enterprises turns out to be much more complicated as the operation encounters many problems, as:

(1) The government decides to keep under the state ownership the enterprises considered as "strategic". The problem, indeed, is to define "strategic" because, when it comes to choose which enterprises to leave to the private investors, the deciders can’t distinguish between the strategic firms and the non-strategic ones;

(2) When this first difficulty is overcome and the enterprises to privatize are selected, another problem arises with regard to the evaluation of their estates. The reason is that when the economy was under the state control, the planners could locate whatever they want (plants, schools, flats...) where they wish, including the private owned estate. Besides, the splitting of large public enterprises in the early eighties into small and medium units was conducted in such a messy way that it is difficult to say what belongs to which firm. It will take several years to smooth out the problem;

(3) The workers oppose a strong resistance to any change, refusing to substitute a situation where they must work hard to one where they receive a part of the oil rent without working. In addition, public firms are over stuffed, a state which cannot be logically tolerated by the potential buyers. Anticipating the troubles that could be caused by the laying off of the surplus workers, the state imposes a clause according to which the bidders for any public enterprise must accept to keep all the workers on for at least five years. This clause is inacceptable and the candidates gave up bidding for the enterprises proposed for privatization;

(4) During the socialist era, the banks played a symbolic rather than economic role: investment is financed by the state which pulls its resources from oil exports and foreign debt; interest rates were fixed administratively, the funds were allocated according to the development plans priorities... So, the banking system remained archaic and the financial institutions are entirely ignorant of how to conduct an operation of privatization;

(5) Most public enterprises are heavily indebted, ill-managed and operate at less than their theoretical capacities; this explains why investors are not rushing to waste their capital in such lemons.

Such rotten environment explains why only a handful of enterprises were privatized so far. Among the successful operations we count the selling of ENAD to the German Henkel and SNS to the Indian Mittal Steel, but also the takeover of ENCG by the Algeria firm La Belle. The remaining enterprises incur important staff cuts which increase the unemployment and receive big subsidies from the state to enhance their competitiveness. But being structurally and deeply ill, the injection of billion dinars does not induce any improvement in the situation of the state-owned firms. The increased price of oil since 2007, led the authorities to consider seriously reconstituting a powerful industrial public sector. Not only, has the government committed itself to help existing firms, but it equally decided to create new firms. Thus, Algeria closes the parenthesis of 20 years of transition to the market economy by returning back to square one. 


\section{Liberalization}

The economic theory widely accepted since decades now (monetarism, supply-side economy, rational expectations school) supports the idea that the state is at the roots of the economic weakness, everywhere in the world. The culprit having been identified, it must be neutralized. So, all around the world the state begins to move back, giving up many of the fields that use to be its attributes for decades if not centuries. The state is systematically replaced by the private initiative, including in sectors that were traditionally public monopoles (police, justice, education...). Algeria decides to go against the stream, trying to build a powerful state when the prevailing general wisdom indicates that an unduly extended state will put the economy in trouble. So far, the uselessly big state has totally failed to manage the economy and to make it productive and competitive. At the outset of the 1990s, it became a matter of life and death to stop the expansion of the state and stabilize it at an acceptable size. More than an option, such policy was necessary one. So, everybody welcomes with relief the first steps of the country in this way in the late 1980s. Even the coming of the IMF is welcomed, despite the hardness of the reforms this institution imposes because it is expected to lead the country to the market type economy. The 1990 law on money and credit creates a breach in the wall of the state (Benissad, 1991) and the code of investments of 1993 enlarges it, while the SAP makes it irreversible. The country changes its philosophy towards the free enterprise but on the field the problems remain, the government seems unable to find the balance between "too much" and "not much", especially with the foreign partners.

\section{Openness}

Since the independence, Algeria remained nearly a closed country dominated by a single actor: the state. All exchanges with the rest of the world were narrowly checked. Nobody can leave the country without a special permission, while heavy taxes at the boundaries are expected to protect the economy and a merciless control is applied on the exchange rate. So the bulk of the funds coming from oil exports and loans from abroad was concentrated in the hands of the state that gives the image of someone who knows what to do and does it well. The country exhibited high growth rates and social indicators were all improving. However, after the crisis of 1986 it became evident that the state-led economy that is insulated from outside influences of all kind (prices and interest rates variation, capital flux, competition...) is not the best way to achieve economic development. Even the greater partisans of this option, recognized that the situation can't continue anymore. It must be ended urgently, because it strangles the economy and leads the country straight to the disaster.

We have yet recalled the new code of investments which constitutes a great step ahead in the process of openness; however, the genuine openness comes with the participation of Algeria to the regional trade area as it signed in 2002 an Association Agreement with the European Union. The rules of the Agreement started operating in September 2005, with the beginning of the progressive tariff dismantling. Later, Algeria joined the Arab free trade area but its openness remains incomplete as:

- It is among the few countries which aren't yet a member of the WTO;

- Foreigners still encounter several difficulties to work in Algeria ${ }^{3}$;

- The state can’t bring itself to give up sincerely and loyally the economic field. The banking system is

\footnotetext{
${ }^{3}$ For example, in 2009, the government decides that FDI must involve an Algerian partner for at least 51\% of the investment.
} 
dominated by public financial institutions and we still count nearly a thousand public-owned enterprises that rely on different forms of support from the government to exist while private investments are always tied with uncertainty because of the unclear and rapidly evolving regulation, heavy bureaucracy...

\section{Macro-economic Stabilization}

Algeria has a steady level of imports while its exports are affected by the least variation in the price of oil. In such situation, a surplus of the BP is far from being a sign of the good health of the economy, and it indicates simply the good shape of the international oil market. In these conditions, equilibrating the exchanges with the rest of the world prove to be a hard task. As Algeria pulls 33\% to 50\% of its GDP from hydrocarbons exports, the BP deficit leads directly to budget deficit, in accordance with one of macro-economics principles. Within the process of transition, Algeria ought to eliminate the two kinds of deficit, stabilize inflation and reduce drastically unemployment. Let's examine these four actions.

The first action is the action on the budget. The contemporary world witnesses a sharp trend for the states size to expand as a result of economic development and the urbanization that accompanies it. In Algeria, the size of the state is even larger because it also plays the role of the major economic actor. The state's needs of funds grew more and more while oil revenues were declining most of the time since 1986, and public enterprises performance was very poor. Consequently, the budget deficit was widening to reach an unbearable level. Lacking time to think about a serious and profound solution, the government rushes to practice black cuts in social sectors (health, education, subsidies to products of large consumption...). As a result, the living standards of the Algerian fall dramatically, throwing the people in a spiral of diseases, poverty that does not spare even the middle classes, and all kind of violence. This was the price to pay to improve the budget stance. As a matter of fact, the budget deficit of -8.7\% GDP recorded in 1993 was transformed into a budget surplus of 3\% GDP in 1997.

The second action is tied to the balance of payment (see Table 3). There are two main ways to bring the balance of payment to the state of equilibrium: we can increase exports or cut back on imports. Increasing exports is a long run strategy which requires a lot of skills and capacities that are extremely rare, whereas the success is never guaranteed. This explains why usually governments choose the easier option, i.e., to reduce imports. The strategy is at the hand of everyone because all it needs is a simple decision and it can be implemented within hours. When a government is urged to realize miraculous results, there is no better way than reducing drastically imports, regardless of the impact on the whole economy. As Algeria relies heavily on external markets to provision itself with a long list of agricultural and industrial products, when the government decides to slowdown imports, the country records terrible shortages of basic needs products (semolina, floor, oil, sugar...), putting itself under the threat of social unrest and riots, once again.

The third action is the action on inflation: one of the scourges of the modern world. It gives the indisputable proof that the short run successes in terms of GDP growth, job creation, and avoiding social discontent and so on, jeopardize the capacity of the country to achieve sound and sustainable results in the long run. The reason is that, governments that lack imagination and the policy-makers who are just worried about staying in power as long as possible, find that it is easier to produce banknotes than goods and services.

In Algeria, public authorities were undoubtedly tempted by such behavior but it is undeniable that they found the courage to resist and to react, essentially by freezing the salaries and increasing the interest rates. The 
policy produced satisfying results as inflation was curved from 31.7\% in 1992 to $2.6 \%$ in 1999, a performance that makes the government feel proud. However, this success is expensively paid by the households whom have the insight that they are becoming poorer. The population reacted violently through demonstrations and strikes to express their discontent and opposition to the reforms, contributing to slow them down if not causing their failure.

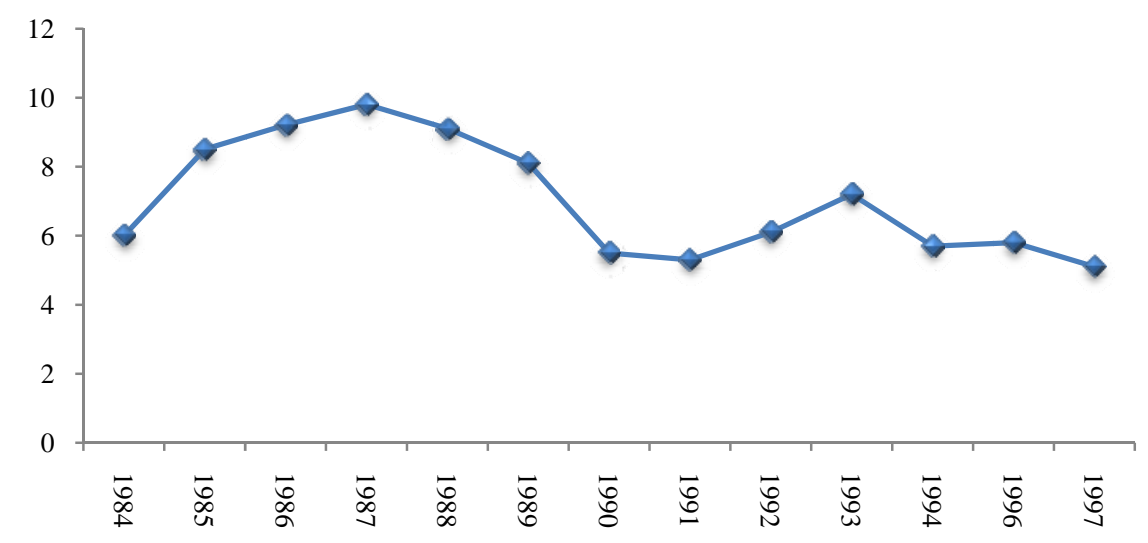

Figure 4. Share of education in GDP. Source: World Bank: World Development Indicators, 1999.

Table 3

Results of the Balance of Payment (Billion Dollars)

\begin{tabular}{lllllll}
\hline 1997 & 1998 & 1999 & 2000 & 2001 & 2002 & 2003 \\
\hline 1.5 & -1.7 & -2.41 & 7.964 & 6.368 & 3.925 & 8.284 \\
\hline
\end{tabular}

Note. Source: Retrieved April 15, 2011, from Office National des Statistiques, www.ons.dz.

The last action is applied to unemployment. In Algeria, unemployment is a recurrent phenomenon since independence. The different governments tried to reduce it by over-creating jobs in the administration and even in the industry ${ }^{4}$ but around the late eighties, this kind of solution reaches its limits. Instead of looking for genuine solutions and create employment opportunities in order to face the dramatic shortage of job offers, the authorities preferred a short-sighted policy, offering hundred thousands of temporary employment contracts to the job seekers. As a result, the rate of unemployment went on increasing as if nothing was able to stop it ${ }^{5}$, going from about $11 \%$ in 1985 to $29.7 \%$ in 2000 . During the last decade, the government intensified its efforts and launched several employment programs (promoting small business creation, public works, general interest activities...). These different mechanisms seem to be very efficient as the unemployment rate fell to $10.3 \%$ in 2010 according to official data, that is dividing by three the level of joblessness recorded at the outset of the decade. Whatever impressive this result may appear, one must bear in mind two things. First, a significant share of new jobs is either temporary or work at home. For the rest, job offer is supported by high government spending led growth made possible by the sharp increase in oil export revenue. Second, even if we don't doubt about the truth of the data, an unemployment rate above $10 \%$ is still high for a country that relies heavily on imports for all its needs (consumption products, capital and intermediate goods of all kind) while its exports are limited to crude oil.

\footnotetext{
4 These extra-workers are among the problems that caused the failure of public enterprises.

${ }^{5}$ The quality of the data in Algeria is much questionable as the government makes it saying what it wants. For instance, the official rate of unemployment was close to $30 \%$ in 2000 , but the bulk of neutral analysts agree on the fact that unemployment is higher than that.
} 
Returning on two decades of reforms intended to introduce the mechanisms of a market economy; we can summarize their achievements in three points: the private action takes over the public action in economic activity; the small enterprise replaces the big enterprise and the economic efficiency comes in the top of the country's priorities well before social objectives. However, the reforms did not succeed in enhancing the efficiency of the national production system and the government is still looking for a way to put the economy on sustained growth and development path.

\section{Why Algeria Is Still Transiting, 20 Years After the Beginning of the Reforms?}

Transition is supposed to be a short period during which we leave a given state of things or a system to enter in another one. This transformation can be achieved rapidly following a choc therapy, as it was the case in Poland. To avoid the brutality of introducing all the reforms at once, governments can choose to proceed progressively by implementing the reforms step by step. In Algeria, it is not clear until now which of these solutions is actually adopted. The population has incurred the brutality and the hardness that characterizes the big bang kind of transition but is incurring them for 20 years. The country has given up the main features of socialism (planning, the state as the major economic actor...) but did not replace them by the main mechanisms of the market economy. Algeria is settled in a sort of no-man's-land full of doubt and uncertainty as the country does not benefit from the advantages of any of the two systems while it suffers from the drawbacks of both of them. This situation proves to be extremely damaging and paralyzing to both local and foreign investors. It is worth examining how two important actors (FDI and SME) react in such hostile environment.

Let us start with foreign direct investment. Algeria is considered as one of the less attractive countries to the FDI, excepting for the firms investing in oil related activities. As a matter of fact, even after the introduction of the Investment Code of 1993 that welcomes both national and foreign investors, very few firms respond to the call (see Figure 5). This situation could be blamed on two main reasons. First of all, it seems that the wishes of Algeria don't cross those of the foreign firms. The later consider that the advantages offered by the new investment code are largely nullified by several drawbacks (deficient banking system, lack of R\&D, low competitiveness of domestic firms, high level of bribery...). When, it happens that some foreign firms are attracted by the investment opportunities offered by such a rich country and dare to take the risk of investing there, they rapidly change their mind. The reason is that the regions do not make the single effort to attract investors, and the few firms that prospected for a place to locate their activity, ended up by living the country. Local authorities do not have enough materials and logistical means and are not even able to provide correctly for the population daily needs (transportation, refuse collection, maintenance of public infrastructure...) let alone make their region attractive to foreign investors. So, for the moment, foreign firms prefer produce elsewhere and export to Algeria.

Secondly, the authorities did not target the appropriate investors. Geographically, historically and culturally, Algeria is strongly tied to Europe: more than $50 \%$ of its foreign trade takes place with the EU and more than a million Algerians live in this continent. Therefore, when the country decided to open its doors to FDI, public authorities thought that they should naturally try to attract European investors and devoted most of their energy in developing a marketing campaign in the direction of European enterprises, above all, the French ones. From our point of view, here was the mistake. Globally, the UE has no interest to invest in Algeria, it can limit its activity to 
exporting to this country as the distance is short and the costs of transport are low. In addition, the country is not leaned back on an important market, because it is circled by the desert of Sahara beyond which are located the poorest countries of the world (Mauritania, Niger, Mali, Burkina Faso, Chad...). Algeria ought rather to be the ideal basis for American and Asian firms that seek to settle near Europe that is regarded as the greatest market in the world (more than 16,000 billion dollars of GDP) to take advantage from the low cost of North Africa and beat European enterprises on their own ground. However, when we analyze the FDI entering to Algeria, we notice that it attracts neither European nor American firms. The few investors attracted so far are Arabic businessmen who intend to seize the opportunities offered by the opening of the services such as mobile telephony, banking, hostelry... For the rest, Algeria's economy continues to rely on the old and precarious public enterprises and the small privates enterprises.

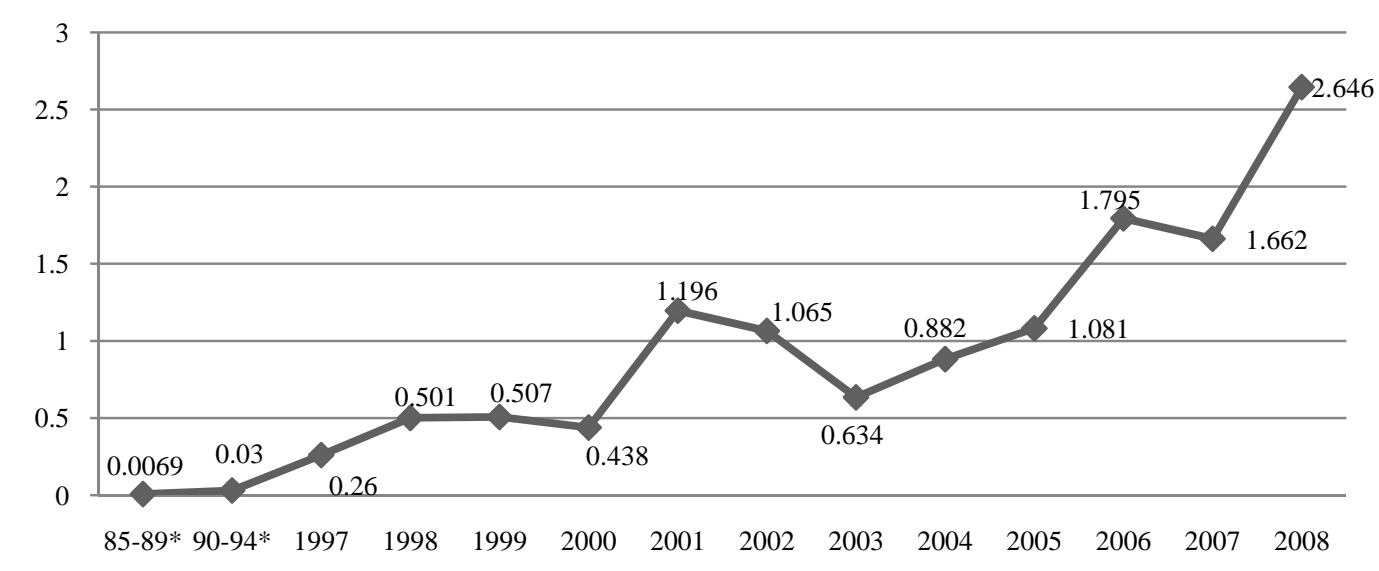

Figure 5. Evolution of FDI inflows to Algeria (billion dollars). ${ }^{*}$ : Annual average. Source : UNCTAD.

What about the SMEs? This category of firms, particularly the micro-enterprises (employing less than 10 persons), offers a set of advantages, that make them very suitable for developing countries. They are labor-intensive, they need little capital, they usually require no technology or high skilled management and they have the capacity to adapt to the market evolution at very low cost. Given these remarkable qualities, SME are viewed as the panacea to the problem of high unemployment in Algeria (CNES, 2002). Overwhelmed by the important number of the jobless that keep growing, the government decided to promote the entrepreneurship as a means to combat joblessness especially among the young people. The authorities think naively that it is possible to realize the miracle of transforming jobless into businessmen by simply offering them some financial support and exempting them from paying taxes. For their part, thousands of young unemployed adhere to the idea of creating their own job by starting a small business, as they are discouraged by months and even years of unfruitful job search. The National Agency for Promoting Youth Employment (ANSEJ) indicates that by the mid-2009, it helped creating 105,300 microenterprises that employ around 299,000 persons. The sector of the SME grew also (336,000 SME excluding crafts) owing to the engagement of those capital owners who seized the opportunity offered by the liberalization of economic activity.

Visibly, the government's purpose of creating jobs through promoting private investment in the form of SME is very successful. By mid-2009, the number of SME, including single craftsmen and micro-enterprises 
created by young jobless attained more than 570,800, employing 1,650,000 persons (Ministry of SME and crafts). However, when we study more seriously this performance, we find that it is just an illusion of success. The SME development has just helped to solve the problems of individuals but not those of the nation. The investors choose to put the bulk of their funds in the least risky, but less sustained growth enhancing activities. Following the line of lesser slope, they favor building and public works (35\% of the enterprises), trade and distribution (18\%), transport and communication (9\%) and services to households (7\%) (see Figure 6). The only quality of such enterprises and such sectors of activity is to create jobs; no more. A country can't rely on such firms to export or to reduce the burden of imports, for example. The concern of the owners is more surviving than being productive and competitive; our inquiries indicate that the bulk of them don't wish to export or to extend the size of their business.

To sum up, we can say that the reforms aiming at freeing investment in Algeria has so far resulted in substituting precarious small enterprises to deficient big state-owned firms (Kheladi, Idir, Alilat, \& Bedjguellal, 2008). Is this a suitable deal? The question deserves to be discussed because today, as it was the case half-century ago, the Algerian economy remains underdeveloped and highly dependent on hydrocarbons despite its huge growth potential.

\section{The Growth Prospects}

Despite its rather disappointing recorded economic performance so far, Algeria is endowed with an important growth potential which needs to be developed and exploited. Let us first find out what feed this potential and then look at the necessary actions in order to take advantage from it.

\section{The Sources of the Growth Potential}

There is a set of factors making us feel optimistic about the country's capacity to achieve an economic takeoff and sustain high growth in order to join the emerging countries. These factors can be summarized in the following points:

- Algeria displays today a pro-growth demographic profile. Until the mid-nineties, the population grew rapidly, exhibiting one of the highest demographic rates in the world (more 3\% a year). But, owing to a family planning program, large vaccination campaigns, a free health care system, a relative improvement in standards of living... population growth has been curved to less than $1.5 \%$ a year during the last decade. Consequently, the age dependency ratio ${ }^{6}$ decreased from 94\% in 1986 down to 47\% in 2009 (World Bank data base), which means more possibilities to save and invest. In addition, this demographic evolution together with the rising labor force participation, led to a rapid expansion of the working-age population (about 3.8\%). The flux of new labor market entrants will particularly remain important at least until 2015. In other words, the country is endowed with a huge labor capacity to feed and sustain growth;

- If we accept the convergence hypothesis, then the per capita GDP indicates that the country has to go a long way before achieving the living standards of the rich countries. Figure 7 shows that the per capita GDP of Algeria is equivalent to less than $25 \%$ that of the major developed countries and represents between 60 and $80 \%$ of the per capita GDP of emerging markets. In the year of 2009, Algeria's performance was less than that of its neighbor Tunisia;

\footnotetext{
${ }^{6}$ Defined as the ratio of dependent (people younger than 15 or older than 64 ) to the working-age population (those aged 15-64).
} 


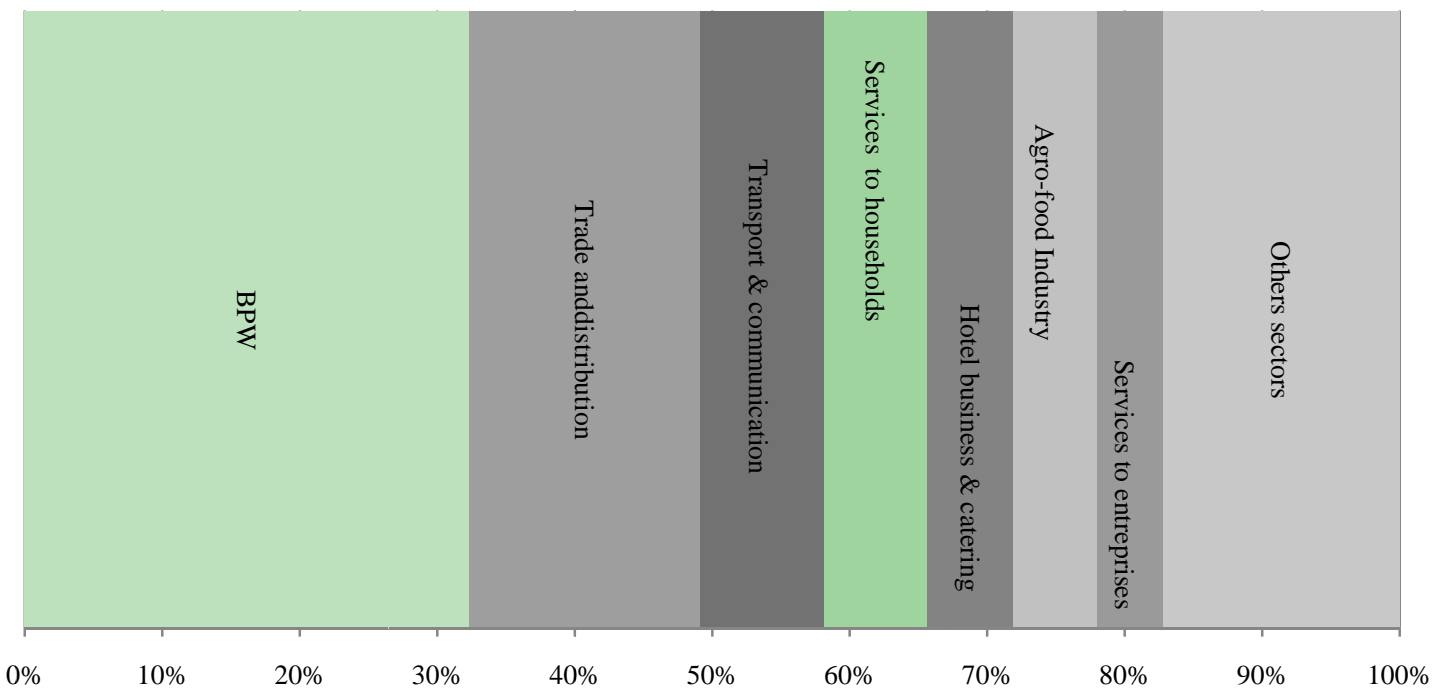

Figure 6. The main sectors of activity of SME. Source: Ministry of the SME and crafts.

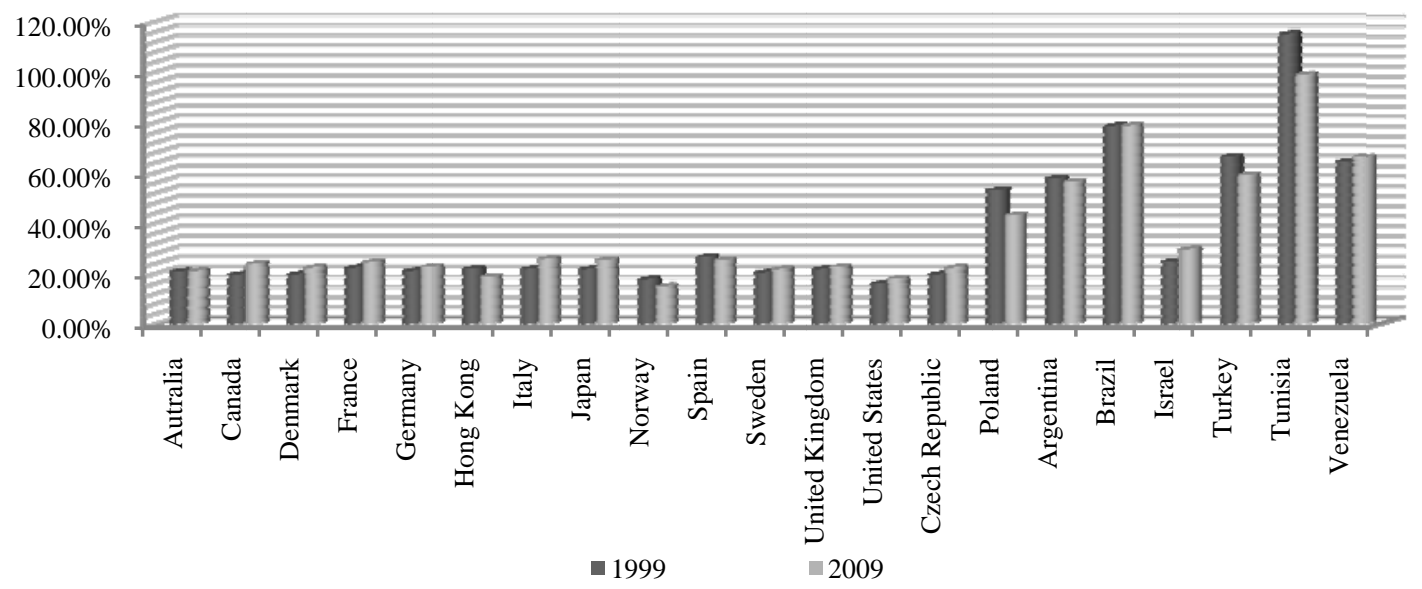

Figure 7. Algeria’s per capita GDP (PPP, current \$) as a percent of that of selected countries. Source: Our calculation on the basis of the World Bank data.

- The performance of the sector which plays a key role in the long run development process, we mean industry, has been very disappointing. The public production has been decreasing since the late eighties (see Table 2). The private industry managed to make up for the deceiving public one, as it exhibited a positive, though low, growth rate. But as mentioned above, private investment presents a major shortcoming: it is concentrated on activities which do not contribute to foster the competitiveness of the country in the world market. As it is illustrated by the Figure 8, the share of manufactured products in GDP or exports is low compared to other Arab countries. The share of intermediate and high technological products in total manufacturing or exports is even lower. This is an issue of concern in the era of knowledge economy;

- The country may make a better use of the stock of capital and infrastructure accumulated so far. Algeria ought also to develop many other activities neglected until now. Beside hydrocarbons, the country is richly endowed with other natural, historical and cultural resources that make the development of activities such as agriculture, fishing, tourism and crafts, a viable option given that more funds and interest are devoted to them; 


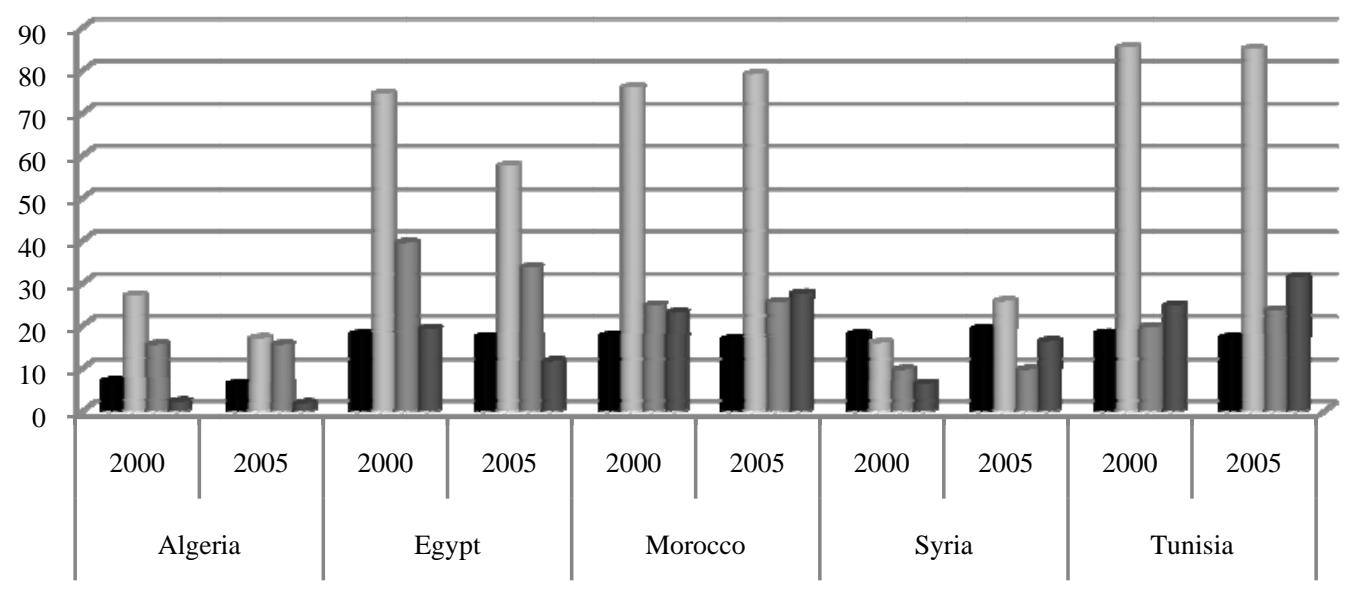

- Share of manufacturing value added in GDP

Share of manufactured products in exports of goods and services

- Share of intermediate or high technology products in total manufacturing

- Share of intermediate or hign technology products in exports of manufactured products

Figure 8. Comparing Algeria with some Arab countries in terms of industrial performance. Source: UNIDO, 2009.

- In the past, total factors productivity growth has not contributed to overall growth in the country. Growth has rather resulted from the injection of capital and labor while little attention has been paid to the efficiency with which these factors are used. This is what the TPF evolution indicates (see Table 4). Hence, there is room for significant productivity improvement, and correlatively, high growth prospects for the following years.

Table 4

TPF: Comparing Algeria, Morocco, Tunisia and East Asia (Average Annual Rate of Growth, \%)

\begin{tabular}{|c|c|c|c|c|c|c|c|}
\hline Region & Year & PIB & Capital stock & Labor force & TFP1 & Human capital & TFP2 \\
\hline \multirow[t]{3}{*}{ Algeria } & 1970 & 5.7 & 8.7 & 3.2 & 0.3 & 4.4 & -0.4 \\
\hline & 1980 & 2.5 & 4.9 & 3.8 & -1.8 & 5.5 & -2.4 \\
\hline & 1990 & 1.5 & 1.0 & 3.8 & -1.1 & 5.0 & -1.8 \\
\hline \multirow[t]{3}{*}{ Morocco } & 1970 & 5.6 & 8.8 & 3.2 & 3.0 & 4.1 & -0.4 \\
\hline & 1980 & 3.6 & 4.9 & 2.6 & -2.6 & 3.4 & -0.4 \\
\hline & 1990 & 2.2 & 3.5 & 2.5 & 1.2 & 3.4 & -1.2 \\
\hline \multirow[t]{3}{*}{ Tunisia } & 1970 & 7.4 & 7.0 & 3.6 & 2.4 & 5.1 & 1.5 \\
\hline & 1980 & 3.7 & 4.6 & 2.7 & 0.3 & 3.7 & -0.4 \\
\hline & 1990 & 4.8 & 3.3 & 2.9 & 1.7 & 4.0 & 1.0 \\
\hline \multirow{3}{*}{ East Asia } & 1970 & 7.7 & 10.6 & 3.1 & 1.6 & 4.1 & 1.1 \\
\hline & 1980 & 6.1 & 8.5 & 2.7 & 1.1 & 3.4 & 0.7 \\
\hline & 1990 & 6.2 & 8.5 & 2.2 & 1.4 & 3.0 & 0.9 \\
\hline
\end{tabular}

Note. Source: Pissarides and Verganzones-Varoudakis, 2007.

\section{Unlocking the Growth Potential: Some Policy Recommendations}

Initiating a growth spurt seems relatively easy as a number of countries experienced at least a period of 
growth acceleration since the 1950s. This is the case of Taiwan (1961), South Korea (1962), Brazil (1966), and Singapore (1968) and there are also examples of countries that do not stick in the minds of the economists and development specialists because their experience was short-lived. In this category, we put Botswana (1966), Syria (1969), Algeria (1975) and Egypt (1976) (Hausmann, Pritchett, \& Rodrik, 2005). The failure of Algeria so far to sustain growth dynamics should be looked at as a lesson for public authorities in order to avoid repeating the mistakes of the development experience of the seventies when investment was concentrated on oil and heavy industry. During the last decade, the country achieved a growth rate above $4 \%$ during four consecutive years (4.7\% in 2002, 6.9\% in 2003, 5.2\% in 2004, and 5.1\% in 2005) before falling again to $3 \%$ or less. However, it was not a suitable kind of growth as it was driven by public investment devoted to a great extent to the "non-tradable" sectors, mainly, construction and public works. Consequently, public spending boosted domestic demand instead of stimulating supply and resulted in a surge in imports and threatened the price stability. Having shown its limits, the option of public spending led growth must be replaced by a strategy that makes much room to private initiative. This is the only way to succeed in facing the immediate objective of creating great number of productive jobs, and the long-term challenge of strengthening and sustaining economic growth. The main actions that need to be urgently undertaken touch the following aspects.

First, the country must complete the process of transition to a market economy. We have mentioned above that the most important reforms initiated in the nineties are lagging compared to Eastern Europe countries that went from a planed to a market economy. In fact, ensuring macroeconomic stability appears to be the only positive aspect of the reform. The restructuring/privatization of public firms and banks is awaiting, the state remains the most important investor, and important institutions for the good functioning of a market economy (reliable system of information, stock market, efficient banking system...) are lacking.

Second, it must set up a friendly business climate. There is a widespread recognition by the observers of the national economy, the international institutions experts, local and foreign firms, that the country is characterized by a hostile investment climate (see Table 5). This explains why foreign direct investment continues to fly across the country to settle in Morocco, Tunisia or elsewhere and why local enterprises are not so keen to undertake risky investment and limit themselves to small and less productive, but secure activities.

Table 5

Algeria's Ranking in Doing Business 2008 and 2010

\begin{tabular}{lcc}
\hline & 2008 & 2010 \\
\hline Ease of doing business & 125 & 136 \\
Starting a business & 131 & 148 \\
Dealing with licenses & 108 & 110 \\
Employing workers & 118 & 122 \\
Registering property & 156 & 160 \\
Getting credit & 115 & 135 \\
Protecting investors & 64 & 73 \\
Paying taxes & 157 & 168 \\
Trading across borders & 114 & 122 \\
Enforcing contracts & 117 & 123 \\
Closing a business & 45 & 51 \\
\hline
\end{tabular}

Note. The number of ranked countries was 178 in 2008, and 183 in 2010. Source: World Bank: Doing Business 2008, 2010 Algeria. 
Third, Algeria must favor investments in human capital and R\&D activities. Technological advances and ideas constitute today the engines of economic progress and the competitiveness of a country is no more measured by its natural or financial resources or its stock of physical capital. It is rather appreciated through its capacity to develop new ideas, absorb the knowledge developed elsewhere and to transform them into new goods and processes. With this regard, a huge gap separates Algeria from the countries of the Mediterranean Sea region, let alone the comparison with the newly industrialized states. Public authorities should seriously tackle this problem since now. More than putting more funds in human capital formation and R\&D activities, the urging action is to reform the education/formation system and secure the necessary —other than financial-conditions to promote R\&D (Khelfaoui, 2001; Kheladi, Arhab, \& Mancer, 2009).

Fourth, it must integrate the world economy. It will not serve the cause of national economy to stay away from the ongoing globalization process. In the meantime, joining the movement should not be understood as just to bring down trade barriers, putting the local production system under harsh competition for which it is not ready (ONUDI, 2006; Benabdellah, 2007). Integrating the world economy means to exploit the opportunities offered by the openness of the partners in order to promote national products. We think that Algeria can easily exploit some niches given that it put the necessary energy and effort. An export possibility is offered by agricultural products. We have described, above, the dark side of Algeria's agriculture, but things aren't entirely as bad as it seems, the country owns several advantages which deserve to be recalled quickly.

- Wines: Until early seventies, the country was the major exporters of wines, in the world. Problems of marketing on the world market constrained the state to give up the activity and to dig up the vineyard. Today, everyone knows that a bottle of good wine brings in more than a barrel of crude oil;

- Dates: Algeria appears among the three or four countries producing dates worldwide. In addition to this, its product is famous for being of top quality;

- Olive oil: The country produces important quantities of olive oil, but the activity remains traditional and less competitive than that of countries such as Spain, Italia or Tunisia;

- Sheep: With nearly 20 millions of heads, Algeria can be considered as the country of the sheep, but the activity is more cultural than economic. The breeders do not work to provide the market with a good quality meat but simply to own sheep, a form of wealth;

- Citrus fruits: In Algeria water mixes perfectly with sun to produce citrus fruits of first quality (orange, lemon, mandarin...).

Another promising activity that needs seriously to be taken in hand is tourism. With its wide and diversified territory, culture and history, Algeria offers more potentialities than Morocco, Tunisia and Egypt together. Despites such endowment, it receives no more than 1.5 million tourists yearly, among whom one million of Algerians emigrants visiting their families. Tourism could create hundreds thousands employment opportunities and provide billion dollars of hard currency. Until now, the government limits itself to speak about but no one dare to join the gesture to the speech, even if strategies are sometimes drawn (Ministry of Tourism, 2006).

\section{Conclusion}

The transition to a market economy engaged since the late eighties in Algeria got locked after 20 years of reforms. So, the country operates today under a system made of mixed drawbacks of both socialism and 
capitalism but with the advantages of none of them. As oil price remained at a high level since 2003, the government manages to sustain economic activity through its large investment spending and ensure a minimum social stability using public employment programs and social transfers. But this option endangers the future development of the country. To avoid another recession that will come with a drop in oil prices, public authorities have better do to prepare the country to this possibility. The main action to undertake consists of conducting all the necessary reforms to let market mechanism operate; ensuring a friendly business climate to promote national private investment and FDI; investing in human capital and R\&D activities and joining the international economic integration movement. These actions are of paramount importance if the country is to take advantage of its growth potential, which is actually huge.

\section{References}

Bedrani, S. (2002). Développement et politique agroalimentaire dans la région Méditerranée. Algérie. CIHEAM, Rapport annuel.

Benabdallah, Y. (2007). L’économie algérienne entre réformes et ouverture: quelle priorité? Communication au colloque international Enjeux économiques, sociaux et environnementaux de la libéralisation commerciale des pays du Maghreb et du Proche-Orient, $\quad 19-20 \quad$ octobre, $\quad$ Rabat, $\quad$ Maroc. $\quad$ Retrieved from http://www.gate.cnrs.fruneca07communications\%20pdfBenabdallah-Rabat07.pdf

Benissad, H. (1991). La réforme économique en Algérie. Alger. OPU.

Conseil National Economique et Social. (1999). Rapport préliminaire sur les effets économiques et sociaux du plan d’Ajustement structurel (PAS). Retrieved from http://www.cnes.dz

Conseil National Economique et Social. (2002, April). Pour une politique de développement de la PME en Algérie. Alger

Hausmann, R., Pritchett, L., \& Rodrik, D. (2004). Growth accelerations. NBER working paper No. 10566.

Kheladi, M., Arhab, B., \& Mancer, E. (2009). Essai d’analyse du triptyque : Emploi-Croissance-Productivité; avec référence à l’Algérie. Projet de recherche No. M0620060097, université de Béjaia. Bajaïa.

Kheladi, M., Idir, M., Alilat, T., \& Bedjguellal, F. (2008). A l'ère de la mondialisation, la PME peut-elle constituer une voie de développement pour l’Algérie? Projet de recherche No. M0601/51/06. Université de Béjaïa. Béjaïa.

Khelfaoui, H. (décembre 2001). La science en Algérie. In R., Waast, \& J. Gaillard. (Eds.), La science en Afrique à l'aube du 21ème siècle. Paris. IRD.

Madouche, H. (1988). L'entreprise et l'économie Algérienne, quel avenir? Alger: Laphomic.

Ministère de la Planification et de l’Aménagement du Territoire. (1980). Bilan économique et social de la décennie 1967-1978, document interne.

Ministry of Tourism. (2006). Politique de développement du secteur du tourisme; horizon 2015

Organisation des Nations-Unies pour le Développement de l’Industrie. (2006). Programme intégré pour l'amélioration de la compétitivité et l’appui à la restructuration industrielle en Algérie. Vienne.

Pissarides, Ch., \& Verganzones-Varoudakis, M. A. (2007). Labor markets and economic growth in the MENA region. In J. Nugent, \& H. Pesaran (Eds.), Explaining growth in the Middle East. Amsterdam and Oxford, Elsevier.

United Nations for Industrial Development Organization. (2009). Breaking in and moving up: New industrial challenges for the bottom billion and the middle-incomes countries. Industrial Development Report, Vienna.

World Bank. (2008). Doing Business 2008 Algeria. Washington

World Bank. (2010). Doing Business 2010Algeria. Washington. 